\begin{tabular}{ccc} 
Tersedia online di: http://ejournal-balitbang.kkp.go.id/index.php/jppi & JURNAL \\
e-mail:jppi.puslitbangkan @ gmail.com & PENELITIAN \\
PERIKANAN & INDONESIA \\
JURNAL PENELITIANPERIKANANINDONESIA & Volume 26 Nomor 1 Maret 2020 \\
p-ISSN: 0853-5884 & e-ISSN: 2502-6542 \\
Nomor Akreditasi RISTEKDIKTI: 21/E/KPT/2018 & \\
\hline
\end{tabular}

\title{
EFISIENSI FAKTOR PRODUKSI PERIKANAN PUKAT CINCIN DI PELABUHAN PERIKANAN TEGALSARI, KOTA TEGAL, JAWA TENGAH
}

\author{
EFFICIENCY OF PURSE SEINE FISHERY PRODUCTION \\ IN FISHING PORT OF TEGALSARI, TEGAL, CENTRAL OF JAVA
}

\author{
Astrid Wijayanti ${ }^{\star 1}$, Eko Sri Wiyono² dan Akhmad Solihin ${ }^{2}$ \\ ${ }^{1}$ Mahasiswa PS Teknologi dan Manajemen Perikanan Tangkap, Departemen Pemanfaatan Sumberdaya Perikanan, Fakultas \\ Perikanan dan IImu Kelautan IPB, JI. Lingkar Akademik Kampus IPB Darmaga, Bogor-Jawa Barat, Indonesia \\ ${ }^{2}$ Departemen Pemanfaatan Sumberdaya Perikanan, Fakultas Perikanan dan IImu Kelautan IPB, JI. Lingkar Akademik Kampus IPB \\ Darmaga, Bogor-Jawa Barat, Indonesia \\ Teregistrasi I tanggal: 28 Mei 2019; Diterima setelah perbaikan tanggal: 17 Maret 2020; \\ Disetujui terbit tanggal: 26 Maret 2020
}

\begin{abstract}
ABSTRAK
Pukat cincin adalah salah satu alat penangkapan ikan yang dominan digunakan di Pelabuhan Perikanan Pantai (PPP) Tegalsari, Kota Tegal, Jawa Tengah, yang belum optimal dalam pengoperasiannya. Tujuan penelitian ini adalah menentukan faktor-faktor produksi serta menghitung produktivitas, efisiensi, dan elastisitas faktor produksi kegiatan penangkapan purse seine. Metode yang digunakan dalam penelitian ini adalah metode survei dengan analisis deskriptif (grafik dan gambar) dan kuantitatif (Cobb-Dougla). Hasil penelitian menunjukkan faktor-faktor produksi yang berpengaruh simultan terhadap produksi hasil tangkapan purse seine adalah ukuran kapal, jumlah BBM, kegiatan penangkapan, dan lama operasi. Rata-rata produktivitas unit penangkapan purse seine tertinggi terjadi pada tahun 2014 sebesar $370.877,22 \mathrm{~kg} /$ trip, sedangkan produktivitas unit penangkapan purse seine tahun 2013 dan 2015 berturut-turut sebesar 340.784,86 $\mathrm{kg} /$ trip dan 351.956,60 kg/trip. Penggunaan faktor produksi ukuran kapal dan lama operasi sudah tidak efisien yang dapat menurunkan hasil produksi, sedangkan penggunaan jumlah BBM dan kegiatan penangkapan belum efisien yang penambahannya akan menaikkan hasil produksi.
\end{abstract}

Kata Kunci: Efisiensi; elastisitas; faktor produksi; produktivitas; pukat cincin; PPP Tegalsari

\begin{abstract}
Purse seine is one of the dominant fishing gear used in the Beach Fishery Harbor (PPP) Tegalsari, Tegal, Central Java that has not been optimal in operation. The purpose of this study is to determine the factors of production and to calculate the productivity, efficiency, and elasticity of production factors of purse seine fishing activities. The methods used in this research are survey methods with descriptive (graphs and pictures) and quantitative (Cobb-Douglas) analyses. The results showed production factors that simultaneously influence towards the production of purse seine catches are the size of the vessel, the amount of fuel, fishing activities, and the length of operation. The average productivity of purse seine fishing unit was the highest in 2014 amounted to $370,877.22 \mathrm{~kg} /$ trip, while the productivity of purse seine fishing unit in 2013 and 2015 amounted to $340,784.86 \mathrm{~kg} /$ trip and $351,956.60 \mathrm{~kg} /$ trip, respectively. The use of production factors ofthe ship size and the age of ships are already inefficient that can reduce the yield, while the use of the amount of fuel and fishing activities are not efficient yet that the addition will increase the production output.
\end{abstract}

Keywords: Efficiency, elasticity, productivity, production factors, purse seine, Tegalsari fishing port 


\section{PENDAHULUAN}

Kota Tegal memiliki sarana pelabuhan perikanan yang dikenal dengan nama Pelabuhan Perikanan Pantai (PPP) Tegalsari, yang dilengkapi tiga TPI, yaitu TPI Jongor/ Tegalsari, TPI Pelabuhan, dan TPI Muarareja. Pelabuhan ini berperan sebagai penyuplai kebutuhan ikan di Kota Tgal dan sekitarnya. PPP Tegalsari terletak di pesisir Pantai Utara Jawa, secara geografis berada posisi $109^{\circ} 10^{\prime} 0^{\prime \prime} \mathrm{BT}$ dan $7^{\circ} 1^{\prime} 0^{\prime \prime}$ LS. Kegiatan penangkapan ikan di laut dilakukan oleh nelayan untuk memenuhi kebutuhan lokal dalam bentuk ikan segar atau sebagai bahan ikan olahan dalam bentuk pindang maupun ikan asin (Bappeda Tegal, 2011). Terdapat 2 jenis alat penangkapan ikan yaitu cantrang dan pukat cincin banyak digunakan oleh nelayan di PPP Tegalsari. Namun saat ini cantrang termasuk alat penangkapan ikan yang dilarang penggunaannya sesuai dengan Peraturan Menteri Kelautan dan Perikanan No 71 Tahun 2016. Sehingga jenis alat penangkapan pukat cicin merupakan jenisa alat penangkapan ikan dominan yang mendaratkan hasil tangkapan.

Pukat cincin tergolong jenis alat penangkapan ikan berupa jaring, berbentuk kantong empat persegi panjang yang terdiri dari sayap, badan dilengkapi pelampung, pemberat, tali ris atas, tali ris bawah dengan atau tanpa tali kerut (pengerut), dan salah satu bagiannya berfungsi sebagai kantong yang pengoperasiannya melingkari gerombolan ikan pelagis (Subani \& Barus, 1989; SNI 7277.3:2011). Hasil tangkapan alat tangkap pukat cincin yang didaratkan di PPP Tegalsari merupakan jenis ikan pelagis kecil, seperti: kembung, selar, layang, tembang, dan banyar (Suharso et al., 2006).

Armada penangkapan ikan di PPP Tegalsari sudah demikian banyak sehingga persaingan dalam kegiatan penangkapan ikan menjadi semakin tinggi. Persaingan tersebut direspon nelayan dengan melakukan perbaikan faktor produksi dengan cara menambah, memperbesar, atau mengganti faktorfaktor produksi yang dianggap mempengaruhi keberhasilan produksi penangkapan ikan (Wiyono, 2014). Penggunaan faktor-faktor produksi yang dilakukan nelayan hanya berdasarkan nalurinya, bukan atas kebutuhan yang memadai sehingga penggunaan faktor-faktor produksi tersebut belum tentu efisien dan tepat guna.

Upaya untuk mencapai proses produksi yang optimum, dapat diupayakan dengan menggunakan faktor produksi yang efisien. Efisiensi ditujukan untuk menghindari pemakaian berlebih atau penggunaan faktor produksi yang kurang tepat yang mengakibatkan pendapatan usaha penangkapan ikan tidak sesuai dengan yang diharapkan. Efisiensi dapat dijadikan sebagai indikator dari baik buruknya kinerja sektor perikanan tangkap. Faktor-faktor produksi tersebut perlu dioptimalkan sebagai unit penangkapan ikan yang dioperasikan optimum dan menghasilkan jumlah tangkapan yang sesuai dengan sumber daya yang tersedia.

Setiap proses produksi melibatkan suatu hubungan yang erat antara faktor-faktor produksi yang sangat mempengaruhi terhadap besar kecilnya produksi yang akan diperoleh. Kajian tentang faktor produksi yang mempengaruhi produksi sudah dilakukan oleh beberapa peneliti (Pratama et al., 2016; Kusaini, 2013; Johannes et al., 2015; Urbeta, 2015; Mukhtar, 2008; Musyafak \& Suherman, 2009; Wiyono, 2014). Hasil kajian tersebut secara umum menyebutkan bahwa faktor produksi mempengaruhi hasil tangkapan. Informasi mengenai faktor-faktor produksi yang berpengaruh pada kegiatan penangkapan ikan alat tangkap pukat cincin di PPP Tegalsari belum dilakukan,sehingga perlu dilakukan penelitian ini. Tujuan dari penelitian ini adalah menentukan faktorfaktor utama dari unit penangkapan ikan pukat cincin; menghitung produktivitas alat tangkap, dan efisiensi penggunaan faktor-faktor produksi dari kegiatan penangkapan ikan dengan pukat cincin khususnya yang mendaratkan hasil tangkapan di PPP Tegalsari.

\section{BAHAN DAN METODE Pengumpulan Data}

Penelitian dan pengumpulan data dilakukan di PPP Tegalsari, Kota Tegal, Jawa Tengah pada tanggal 18 Agustus 2016 sampai dengan 7 September 2016. Data primer yang digunakan dalam penelitian ini dikumpulkan dari hasil pengisian kuisioner, hasil wawancara, dan hasil observasi. Metode pengumpulan data yang digunakan dalam penelitian ini adalah metode survey dengan sampelnya adalah nelayan yang menggunakan alat tangkap purse seine di PPP Tegalsari. Jumlah sampel yang digunakan dalam penelitian ini sebanyak 30 armada purse seine dari 168 armada purse seine yang telah ditentukan berdasarkan metode random sampling. Data yang dikumpulkan untuk kapal pukat cincin berupa data hasil tangkapan $(\mathrm{kg})$, lama trip (hari), jumlah ABK (orang), ukuran kapal (GT), jumlah BBM (liter), lama operasi penangkapan ikan (jam), dan kegiatan penangkapan/pelingkaran pukat cincin (hauling). Sedangkan data sekunder yang dikumpulkan berupa data laporan tahunan sensus pendataan produktivitas armada purse seine yang melakukan pendaratan hasil tangkapan di PPP Tegalsari, seperti jumlah trip dan hasil tangkapan per bulan. 


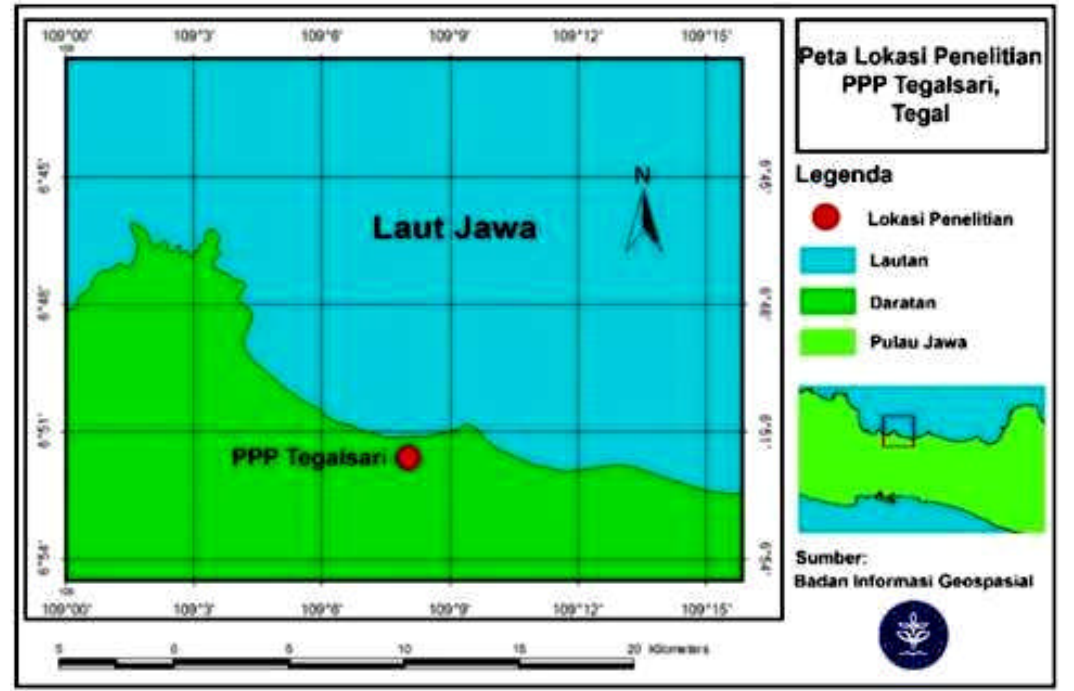

Gambar 1. Peta lokasi PPP Tegalsari.

Figure 1. Location of Center of Fishery Landing of Tegalsari.

\section{Analisis Data}

Pengolahan data dilakukan terhadap data hasil pengisian kuisioner, data hasil wawancara, dan data sekunder. Agar hasil penelitian mudah dipahami, data hasil wawancara diolah menjadi informasi dengan cara menghitung dan mengelompokkan sesuai dengan kelompok dan disajikan dalam bentuk tabel. Guna mengetahui hubungan antara faktor-faktor teknis produksi dengan produksi hasil tangkapan $(\mathrm{Y})$ yang merupakan variabel bebas dan variabel tidak bebas, maka data ukuran kapal $\left(X_{1}\right)$, jumlah BBM $\left(X_{2}\right)$, jumlah trip $\left(X_{3}\right)$, kegiatan penangkapan/pelingkaran jaring $\left(X_{4}\right)$, lama operasi $\left(X_{5}\right)$, jumlah $A B K\left(X_{6}\right)$, dan jumlah alat bantu penangkapan $\left(\mathrm{X}_{7}\right)$ akan diolah berdasarkan rumus Fungsi Produksi Cobb-Douglass dalam bentuk fungsi regresi linear berganda sebagai berikut:

$Y=b_{0}+b_{1} X_{1}+b_{2} X_{2}+b_{3} X_{3}+b_{4} X_{4}+b_{5} X_{5}+b_{6} X_{6}+$ $b_{7} X_{7}+e$

Setelah diperoleh koefisien regresi, maka dilakukan uji $F$ untuk mengetahui hubungan antara variabel bebas $\left(X_{i}\right)$ secara bersama-sama terhadap variabel tidak bebas $(\mathrm{Y})$. Uji t dilakukan untuk mengetahui hubungan masing-masing variabel tidak bebas. Berdasarkan hasil perhitungan dengan Fungsi Regresi Linear Berganda, maka akan dapatkan model yang dapat menjelaskan pengaruh faktor produksi terhadap hasil produksi. Selanjutnya data ini akan digunakan untuk menentukan nilai efisiensi dan elastisitas. Besarnya elastisitas produksi (Ep) dapat digunakan untuk mengukur tingkat efisiensi teknis dan efisiensi ekonomis dari penggunaan input variabel. Tingkat efisiensi teknis dalam penggunaan input tercapai bila $\mathrm{Ep}=1$. Persamaan elastisitas produksi dapat dirumuskan sebagai berikut:

$E p=\frac{\Delta Y}{\Delta X_{i}} \times \frac{X_{i}}{Y}$

Dimana :

$\mathrm{Ep}=$ elastisitas produksi

ÄY = perubahan hasil produksi

$\ddot{A} X_{i}=$ perubahan faktor produksi ke-i

$Y^{\prime}=$ hasil produksi

$\mathrm{X}=$ jumlah faktor produksi ke-i

\section{HASIL DAN BAHASAN \\ Hasil}

\section{Keragaan Perikanan di PPP Tegalsari}

Alat penangkapan ikan yang digunakan nelayan PPP Tegalsari berjumlah 913 unit yang terdiri atas 168 unit alat tangkap pukat cincin, 23 unit jaring insang, 76 unit trammel net, 87 unit jaring cumi, 492 unit cantrang, 19 unit pukat pantai, 46 unit alat bubu lipat, dan 2 unit lain-lainnya. Pukat cincin merupakan jenis alat penangkapan ikan yang dominan digunakan nelayan di, PPP Tegalsari (PPP Tegalsari, 2016).

Berdasarkan laporan di TPI pukat cincin menangkap 8 jenis ikan, yaitu bawal, kembung/ banyar, layang, lemuru, selar/bentong, tembang/jui, tenggiri, dan tongkol. Namun demikian, hasil tangkapan yang dominan adalah layang dan lemuru. Kedua ikan tersebut selama tahun 2013-2016 memberikan kontribusi sebesar $44 \%-56 \%$ atau ratarata sebesar 48\% (Tabel 1). 
Tabel 1. Komposisi hasil tangkapan pukat cincin yang didaratkan di PPP Tegalsari tahun 2013-2015 Table 1. Catch composition of purse seine landed in Fish Landing Site of Tegalsari in 2013-2015

\begin{tabular}{|c|c|c|c|c|c|c|c|c|}
\hline \multirow{2}{*}{ Jenis Ikan } & \multicolumn{6}{|c|}{ Hasil Tangkapan (kg) } & \multirow{2}{*}{ Rata-rata } & \multirow{2}{*}{$\%$} \\
\hline & 2013 & $\%$ & 2014 & $\%$ & 2015 & $\%$ & & \\
\hline Bawal & 14.144 & $0 \%$ & 307.650 & $6 \%$ & 109.525 & $2 \%$ & 143.773 & $3 \%$ \\
\hline Kembung/Banyar & 516.025 & $11 \%$ & 662.345 & $12 \%$ & 552.425 & $11 \%$ & 576.932 & $11 \%$ \\
\hline Layang & 1.392 .582 & $28 \%$ & 1.038 .195 & $19 \%$ & 1.383 .325 & $27 \%$ & 1.271 .367 & $25 \%$ \\
\hline Lemuru & 1.381 .185 & $28 \%$ & 1.313 .412 & $25 \%$ & 889.000 & $18 \%$ & 1.194 .532 & $23 \%$ \\
\hline Selar/Bentong & 406.600 & $8 \%$ & 526.255 & $10 \%$ & 566.825 & $11 \%$ & 499.893 & $10 \%$ \\
\hline Tembang/Jui & 1.106 .550 & $23 \%$ & 598.230 & $11 \%$ & 1.197 .025 & $24 \%$ & 967.268 & $19 \%$ \\
\hline Tenggiri & 39.966 & $1 \%$ & 219.429 & $4 \%$ & 146.300 & $3 \%$ & 135.232 & $3 \%$ \\
\hline Tongkol & 50.250 & $1 \%$ & 672.925 & $13 \%$ & 223.750 & $4 \%$ & 315.642 & $6 \%$ \\
\hline Lain-lain & 0 & $0 \%$ & 2191 & $0 \%$ & 0 & $0 \%$ & 730 & $0 \%$ \\
\hline Jumlah & 4.907 .302 & $100 \%$ & 5.340 .632 & $100 \%$ & 5.068 .175 & $100 \%$ & 5.105 .370 & $100 \%$ \\
\hline
\end{tabular}

Sumber: Data Hasil Tangkapan TPI Pelabuhan (sudah diolah)

\section{Unit Penangkapan Pukat Cincin}

Pukat cincin merupakan salah satu alat penangkapan ikan yang masuk dalam kelompok jaring lingkar (surrounding nets), umumnya berbentuk empat persegi panjang tanpa kantong, yang digunakan untuk menangkap ikan pelagis yang bergerombol (schooling) (Nomura, 1975 dalam Agustina, 2006). Pukat cincin yang dioperasikan nelayan di PPP Tegalsari berukuran panjang $1500 \mathrm{~m}$ dan dalam $80 \mathrm{~m}$. Jaring terbuat dari bahan polyethilene dengan mata jaring pada badan jaring sebesar 1,5 inci dan 1 inci pada kantong. Dalam satu unit pukat cincin, juga dibutuhkan tali temali sebanyak kurang lebih $1000 \mathrm{~m}$. Disamping itu juga dibutuhkan antara $1000-2000$ buah pelampung yang terbuat dari bahan PVC (Polyvinyl Chloride) dan pemberat dari timah sekitar $60-70$ buah pemberat. Pukat cincin juga dilengkapi dengan cincin yang berfungsi sebagai tempat lewatnya tali kolor. Jumlah cincin yang digunakan berkisar antara $60-75$ buah.

\section{Produktivitas Unit Penangkapan Pukat Cincin}

Hasil tangkapan per unit upaya penangkapan (CPUE) merupakan nilai yang mencerminkan produktivitas armada pukat cincin di PPP Tegalsari. Produktivitas tidak hanya diukur berdasarkan pada jumlah produksinya saja, tetapi tergantung pula pada jumlah trip penangkapannya (Iriana et al., 2012). Produktivitas unit penangkapan pukat cincin di PPP Tegalsari berfluktuasi setiap tahunnya. Produktivitas pukat cincin tertinggi disumbangkan dari ikan layang, sebesar $864.578,125 \mathrm{~kg} /$ trip yang terjadi pada tahun 2013 dan 2015. Produktivitas tertinggi kedua disumbangkan oleh ikan lemuru pada tahun 2014 sebesar $820.882,5 \mathrm{~kg} / \mathrm{trip}$. Sedangkan produktivitas terendah disumbangkan oleh ikan bawal pada tahun 2013 sebesar $8.840 \mathrm{~kg} / \mathrm{trip}$ (Gambar 2).

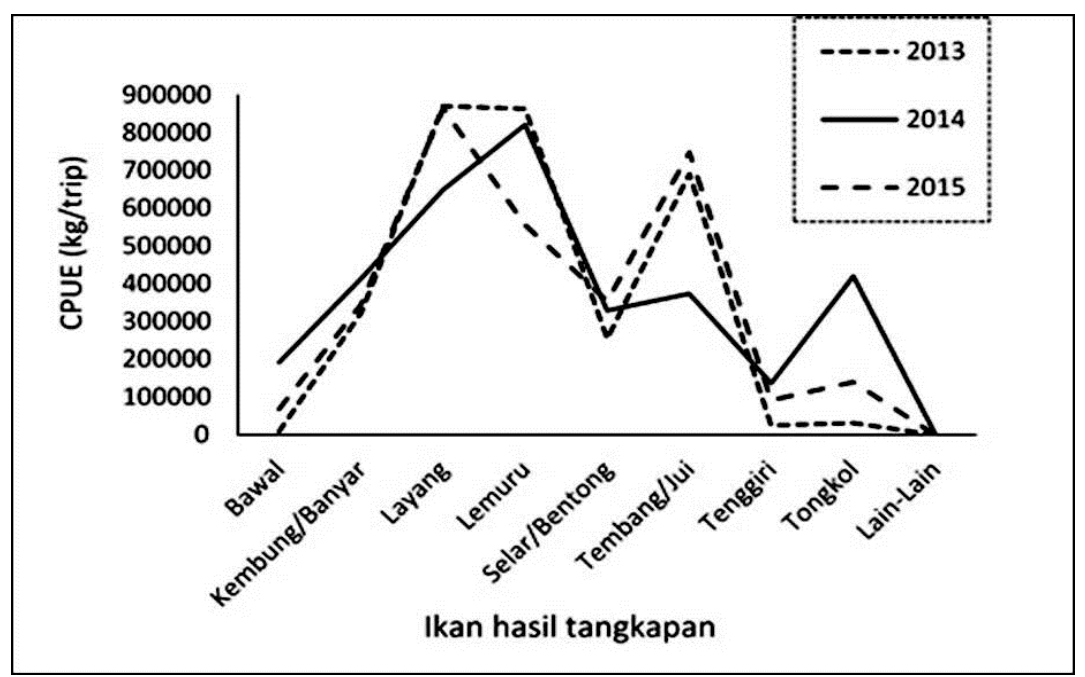

Gambar 2. Produktivitas (kg/trip) hasil tangkapan pukat cincin di PPP Tegalsari.

Figure 2. Productivity ( $\mathrm{kg} / \mathrm{trip}$ ) of purse seine in Fishing Port of Tegalsari PPP. 
Faktor-Faktor Produksi Unit Penangkapan Pukat Cincin

Ukuran kapal $\left(\mathrm{X}_{1}\right)$, jumlah BBM $\left(\mathrm{X}_{2}\right)$, jumlah trip $\left(X_{3}\right)$, kegiatan penangkapan/pelingkaran jaring $\left(X_{4}\right)$, lama operasi $\left(X_{5}\right)$, jumlah $A B K\left(X_{6}\right)$, dan jumlah alat bantu penangkapan $\left(X_{7}\right)$ adalah faktor-faktor produksi yang diduga berpengaruh terhadap penangkapan alat tangkap purse seine di PPP Tegalsari. Analisis faktor produksi dilakukan guna mengetahui hubungan antara faktor-faktor teknis produksi dengan produksi hasil tangkapan yang merupakan variabel bebas dan tidak bebas. Hasil analisis faktor produksi menunjukkan bahwa faktor yang berpengaruh secara simultan terhadap produksi hasil tangkapan ikan, yaitu ukuran kapal $\left(X_{1}\right)$, jumlah BBM $\left(X_{2}\right)$, kegiatan penangkapan $\left(\mathrm{X}_{4}\right)$, dan lama operasi $\left(\mathrm{X}_{5}\right)$ dengan persamaan $Y=$ $63475,605-480,095 X_{1}+1,031 X_{2}+1304,936 X_{4}-$ $727,326 X_{5}+e$.

Tabel 2. Analisis faktor produksi perikanan purse seine di PPP Tegalsari

Table 2. Analysis of purse seine fishery factors production in Center of Fishery Landing of

\begin{tabular}{|c|c|c|c|c|c|}
\hline \multirow[t]{2}{*}{ Model } & \multicolumn{2}{|c|}{$\begin{array}{l}\text { Unstandardized } \\
\text { Coefficients }\end{array}$} & \multirow{2}{*}{$\begin{array}{c}\begin{array}{c}\text { Standardized } \\
\text { Coefficients }\end{array} \\
\text { Beta }\end{array}$} & \multirow[t]{2}{*}{$T$} & \multirow[t]{2}{*}{ Sig. } \\
\hline & B & Std. Error & & & \\
\hline (Constant) & 63475,605 & 17862,722 & & 3.554 & 0.002 \\
\hline GT Kapal $\left(X_{1}\right)$ & $-480,095$ & 263,029 & $-0,353$ & -1.825 & 0.080 \\
\hline $\operatorname{BBM}\left(\mathrm{X}_{2}\right)$ & 1,031 & 0,327 & 0,627 & 3.154 & 0.004 \\
\hline Penangkapan $\left(X_{4}\right)$ & 1304,936 & 478,111 & 0.790 & 2.729 & 0.011 \\
\hline Operasi $\left(X_{5}\right)$ & $-727,326$ & 259,365 & $-0,871$ & -2.804 & 0.010 \\
\hline
\end{tabular}

Sumber: Hasil olahan software statistik

\section{Efisiensi Perikanan Pukat Cincin}

Efisiensi dalam ekonomi sangat berhubungan erat dengan elastisitas. Besarnya elestisitas produksi $\left(E_{p}\right)$ dapat digunakan untuk mengukur tingkat efisiensi dari penggunaan input variabel. Tingkat efisiensi dalam penggunaan input tercapai bila $\mathrm{E}_{\mathrm{p}}=1$, jika nilai $\mathrm{E}_{\mathrm{p}}<1$ atau $E_{p}>1$ maka penggunaan input tersebut tidak efisien (Aprilla et al., 2013). Hasil analisis efisiensi unit penangkapan purse seine di PPP Tegalsari menunjukkan bahwa faktor produksi ukuran kapal $\left(X_{1}\right)$ dan lama operasi $\left(X_{5}\right)$ mempunyai nilai efisiensi yang negatif $\left(E_{p}<0\right)$ sedangkan faktor produksi jumlah BBM $\left(X_{2}\right)$ dan kegiatan penangkapan $\left(X_{4}\right)$ mempunyai nilai efisiensi positif $\left(E_{p}>1\right)$. Analisis terhadap elastisitas produksi menunjukkan bahwa faktor produksi ukuran kapal $\left(X_{1}\right)$ dan lama operasi $\left(X_{5}\right)$ mempunyai nilai elastisitas yang negatif $\left(E_{p}<0\right)$, sedangkan faktor produksi jumlah BBM $\left(X_{2}\right)$ dan kegiatan penangkapan $\left(X_{4}\right)$ mempunyai nilai elastisitas yang positif $\left(E_{p}>0\right)$.

\section{Bahasan}

Ukuran kapal pukat cincin yang mendarat di PPP Tegalsari sangat bervariasi, mulai dari 30-105 GT dengan bahan utama adalah kayu. Semakin besar dimensi utama kapal maka kemampuan kapal untuk membawa jaring dan alat bantu penangkapan ikan lainnya semakin besar, sehingga jarak jangkau fishing ground-nya akan semakin luas (Suryana et al., 2013). Kapal pukat cincin di PPP Tegalsari sudah dilengkapi dengan berbagai alat bantu penangkapan ikan seperti rumpon, lampu, whinch hauler, dan juga palka yang bervariasi jumlahnya setiap kapal pukat cincin. Fungsi dari lampu tersebut sama, yaitu memikat ikan untuk datang, hanya saja berbeda dalam waktu pengoperasiaannya. Secara umum, prinsip penangkapan dengan alat tangkap purse seine di lokasi kajian sama dengan prinsip pengoperasian umumnya (Ayodhyoa, 1981). Berdasarkan pernyataan Monintja \& Yusfiandayani (2011), nelayan purse seine di PPP Tegalsari termasuk dalam kelompok nelayan penuh, dimana mereka menggunakan seluruh waktunya untuk melakukan kegiatan operasi penangkapan ikan. Hal ini menunjukkan bahwa nelayan sangat menggantungkan hidupnya dari kegiatan penangkapan ikan di laut. Keberhasilan menangkap ikan di laut akan menjadi tumpuan keluarga nelayan di Tegalsari. Oleh sebab itu, upaya optimalisasi operasi penangkapan ikan menjadi sangat penting.

Bila ditinjau dari nilai produktivitasnya, purse seine di Tegalsari secara umum menunjukkan fluktuasi. Ikan hasil tangkapan utama, menunujukkan nilai produktivitas tinggi. Hal ini menggambarkan bahwa kelimpahan stok ikan yang bersangkutan masih tinggi (Atmadja \& Nugroho, 2001). Tingginya kelimpahan stok ikan kembung dan lemuru di Tegalsari diduga karena kecakapan nahkoda armada purse seine Tegalsari untuk memperluas daerah penangkapan ikan selain Laut Jawa.

Selanjutnya analisis faktor-faktor produksi penangkapan ikan menunjukkan bahwa uji koefisien regresi linear berganda mempunyai nilai $F_{\text {hit }}(3,612)$ lebih besar dibandingkan dengan nilai $\mathrm{F}_{\text {tabel }}$ dengan 
taraf $0,05(2,46)$. Hasil ini berarti bahwa seluruh faktorfaktor produksi ukuran kapal, jumlah BBM, kegiatan penangkapan, dan lamanya operasi secara simultan menunjukkan pengaruh nyata terhadap produksi hasril tangkapan purse seine. Tetapi, koefisien determinasi $\left(R^{2}\right)$ untuk fungsi produksi perikanan purse seine di PPP Tegalsari hanya mempunyai nilai 0,265. Koefisien determinasi berfungsi untuk menjelaskan seberapa besar perubahan atau variasi suatu variabel dijelaskan oleh perubahan atau variasi pada variabel lain yang menjelaskan (Santosa \& Ashari, 2005). Hal ini berarti bahwa persentasi dari variabel penting yang signifikan mempengaruhi hasil tangkapan seperti pengaruh ukuran kapal, jumlah BBM, kegiatan penangkapan, dan lamanya operasi sebesar $26,5 \%$ dan sisanya dipengaruhi oleh faktor lain yang tidak masuk ke dalam model. Temuan ini memberi makna bahwa faktor yang tidak terkontrol memegang peranan $73,5 \%$. Berdasarkan temuan ini menunjukkan bahwa ketidakpastian kegiatan penangkapan ikan dengan menggunakan purse seine sangat tinggi.

Uji lanjutan dari kajian ini menunjukkan bahwa efisiensi unit penangkapan pukat cincin di PPP Tegalsari untuk faktor produksi ukuran kapal $\left(X_{1}\right)$ dan lama operasi $\left(X_{5}\right)$ mempunyai nilai efisiensi yang negatif $\left(E_{p}<0\right)$ yang menunjukkan bahwa penggunaan faktor produksi sudah tidak efisien, sehingga penambahan faktor produksi tersebut dapat mengakibatkan overcapacity. Hasil penelitian yang menyatakan bahwa ukuran kapal tidak berpengaruh terhadap hasil tangkapan pukat cincin juga diungkapkan oleh Pratama, et al., 2016. Penambahan volume faktor produksi bukannya meningkatkan produksi, tetapi justru kemungkinan menurunkan produktivitas. Penambahan ukuran kapal dan lama operasi mempunyai hubungan langsung dengan biaya operasi penangkapan ikan, sehingga dengan sumberdaya yang tersedia maka penambahan ukuran kapal dan hari operasi diduga tidak meningkatkan produktivitas kapal, sehingga tidak menutupi biaya produksi yang dikeluarkan.

Sedangkan faktor produksi jumlah $\operatorname{BBM}\left(\mathrm{X}_{2}\right)$ dan kegiatan penangkapan $\left(X_{4}\right)$ mempunyai nilai efisiensi positif $\left(E_{p}>1\right)$ yang artinya penggunaan faktor produksi belum efisien, diperlukan strategi pengoptimalan penggunaan jumlah BBM dan kegiatan penangkapan sehingga hasil tangkapan meningkat. Hasil ini mempunyai kemiripan dengan hasil penelitian Rahim et el., 2019 tetapi berbeda dengan hasil penelitan yang dilakukan Budiarti et al., 2015; Pratama et al., 2016. Hasil penelitian yang dilakukan beberapa peneliti tersebut menunjukkan bahwa pukat cincin di beberapa lokasi tersebut mengalami kelebihan input lama waktu trip, bahan bakar, dan ransum. Hasil serupa juga dilaporkan oleh Wiyono \& Hufiadi, 2014 yang menyatakan bahwa lama trip penangkapan ikan mempengaruhi hasil tangkapan ikan.

Jumlah BBM dan kegiatan operasi penangkapan (hauling) sangat berhubungan erat. Penambahan jumlah hauling (operasi penangkapan ikan) akan meningkatan konsumsi BBM yang digunakan dalam kegiatan penangkapan ikan. Hasil analisis ini menunjukkan bahwa jumlah hauling operasi penangkapan ikan perlu ditambahkan frekuensinya sehingga meningkatkan hasil tangkapan dan memperpendek trip operasi penangkapan ikan.

\section{KESIMPULAN}

Berdasarkan hasil penelitian ini dapat disimpulkan bahwa armada purse seine di PPP Tegalsari umumnya berukuran kecil (<10GT). Faktor produksi yang berpengaruh secara nyata terhadap produksi hasil tangkapan purse seine hanya jumlah $\operatorname{BBM}\left(X_{2}\right)$, kegiatan penangkapan $\left(X_{4}\right)$, dan lama operasi $\left(X_{5}\right)$. Hasil nalisis efisiensi menunjukkan bahwa faktor produksi ukuran kapal $\left(\mathrm{X}_{1}\right)$ dan lama operasi $\left(\mathrm{X}_{5}\right)$ mempunyai nilai efisiensi yang negatif $\left(E_{p}<0\right)$, sedangkan faktor produksi jumlah BBM $\left(X_{2}^{p}\right)$ dan kegiatan penangkapan $\left(X_{4}\right)$ mempunyai nilai efisiensi positif $\left(E_{p}>1\right)$. Berdasarkan hasil penelitian ihi, maka beberapa hal yang dapat disarankan adalah: 1) ukuran kapal dan lama operasi penangkapan ikan pukat cincin di PPP Tegal sari tidak perlu ditambah, sementara penggunaan jumlah BBM dan kegiatan penangkapan (hauling) masih mungkin ditambah untuk mengoptimalkan produksi.

\section{PERSANTUNAN}

Penulis mengucapkan terima kasih kepada semua pihak yang telah membantu terlaksananya penelitian ini, khususnya nelayan di Eretan Kulon yang telah membantu terlaksananya penelitian ini. Penulis juga mengucapkan terima kasih kepada penelaah dan mitra bestari yang telah memberikan masukan penyempurnaan tulisan ini.

\section{DAFTAR PUSTAKA}

Agustina, V. E. (2006). Optimasi faktor-faktor produksi armada purse seine di Pelabuhan Perikanan Pantai Eretan Wetan, Indramayu. [Skripsi]. Bogor (ID): Institut Pertanian Bogor.

Aprilla, R.M, Mustaruddin, Wiyono, E.S, \& Zubainarni. (2013). Analisis efisiensi unit penangkapan pukat cincin di Pelabuhan Perikanan Pantai Lampulo, Banda Aceh. Jurnal Teknologi Perikanan dan 
Kelautan. 4 (1), 9-20. https://doi.org/10.24319/ jtpk.4.9-20.

Atmadja, S.B., \& Nugroho, D. (2001). Perikanan pukat cincin mini di pantai Utara Jawa: Distribusi dan Variabilitas Spasial-Temporal Ikan Pelagis. Prosiding Seminar Nasional Keanekaragaman Hayati Ikan. PSIH-JICA-LIPI. Bogor.

Ayodhyoa. (1981). Metode penangkapan ikan (p. 97). Yayasan Dewi Sri. Bogor.

Bappeda Tegal. (2011). Potensi perikanan Laut Tegal.

Budiarti, T.W., Wiyono, E.S., \& Zulbainarni, N. (2015). Produksi optimal pukat cincin di Pelabuhan Perikanan Nusantara Pemangkat, Kalimantan Barat. J. Lit. Perikan. Ind. 21(1), 37-44. DOI: http:/ /dx.doi.org/10.15578/jppi.21.1.2015.37-44.

Iriana, D., Kahan, A. M, Rostika R., Simpati, S., \& Sunarto. (2012). Efektivitas alat tangkap ikan lemuru di Kabupaten Kotabaru, Kalimantan Selatan. Depik, 1(3), 131-135. DOI: https://doi.org/ 10.13170/depik.1.3.282.

Johannes, S., Wisudo, S.H., \& Nurani, T. (2015). Analisis faktor produksi dan kelayakan usaha perikanan purse seine di Kecamatan Salahutu, Kabupaten Maluku Tengah. Jurnal Aplikasi Manajemen. 13 (2), 335-343.

Monintja, D., \& Yusfiandayani, R. (2011). Pemanfaatan sumberdaya pesisir dalam bidang perikanan tangkap. Bogor (ID): Institut Pertanian Bogor (IPB).

Mukhtar. (2008). Analisis faktor-faktor yang mempengaruhi produktivitas kapal purse seine [tesis]. Kendari (ID): Universitas Haluoleo.

Musyafak, R.A, \& Suherman A. (2009). Kapasitas penangkapan kapal pukat cincin di Pelabuhan Perikanan Nusantara Pekalongan. Jurnal Saintek Perikanan, 4(2), 16-23. DOI: https://doi.org/ 10.14710/ijst.4.2.16-23.

Pratama, M.A., Hapsari, T.D., \& Triarsi I. (2016). Faktor-faktor yang mempengeruhi hasil produksi unit penangkapan purse seine (Gardan) di Fishing bAsemPPP Muncar, Banyuwangi, Jawa Timur. Jurnal Saintek Perikanan Indonesia, 11 (2), 120128. DOI: https://doi.org/n 10.14710/ijfst.11.2.120128.
Rahim, A., Hastuti, D.R.D., Firmansyah, Sabar, W., \& Syam, A. (2019). The applied of cobbdouglasproduction function with determinants estimation of small-scale fishermen's catches production. International Journal of Oceans and Oceanography, 13(1), 81-95.

Santosa, P.B., \& Ashari. (2005). Analisis statistik dengan microsoft excel dan SPSS. Yogyakarta (ID): Andi Offset.

Standar Nasional Indonesia. (2011). Kumpulan peraturan alat penangkapan ikan. Direktorat Kapal Perikanan dan Alat Penangkap Ikan. Direktorat Jendral Perikanan Tangkap Kementrian Kelautan dan Perikanan.

Subani, W., \& Barus, H.R. (1989). Alat penangkapan ikan dan udang laut di Indonesia. Jurnal Penelitian Perikanan Laut, 50, 248.

Suharso, Bambang A.N, dan Asriyanto. 2006. Elastisitas produksi perikanan tangkap Kota Tegal. Jurnal Pesisir Laut. 2 (1), 26-35.

Suryana S.A, Rahardjo I.P, Sukandar. (2013). Pengaruh panjang jaring, ukuran kapal, pk mesin dan jumlah ABK terhadap Produksi lkan pada Alat Tangkap Purse Seine di Perairan Prigi, Kabupaten Trenggalek - Jawa Timur. PSPK STUDENT JOURNAL. 1(1), 36-43.

Urbeta, G. A. (2015). Faktor-faktor produksi operasi penangkapan purse seine (pukat cincin) yang berbasis di PPP Bojomulyo, Kabupaten Pati, Jawa Tengah [skripsi]. Bogor (ID): Institut Pertanian Bogor.

Wiyono, E,S. (2014). Optimasi operasi penangkapan ikan gill net di PPN Pekalongan Jawa Tengah. Jurnal Berkala Perikanan Terubuk. 42 (1), 1-8. 